\title{
WHY SHOULD CLIMATE SMART AGRICULTURE BE PROMOTED IN THE INDONESIAN COFFEE PRODUCTION SYSTEM?
}

\author{
YELI SARVINA ${ }^{1,5}$, TANIA JUNE ${ }^{1,2 *}$, SURJONO HADI SUTJAHJO ${ }^{1,3}$, RITA NURMALINA ${ }^{1,4}$ \\ AND ELZA SURMAINI ${ }^{5}$ \\ ${ }^{1}$ Natural Resources and Environmental Management Science. ${ }^{2}$ Department of Geophysics and Meteorology, Faculty of \\ Mathematics and Natural Sciences. ${ }^{3}$ Department of Agronomy and Horticulture, Faculty of Agriculture. ${ }^{4}$ Department \\ Agrobusiness, Faculty of Economics and Management Bogor Agricultural University, Bogor, West Java, Indonesia. \\ ${ }^{5}$ Agroclimatology and hydrology, Indonesian Agency for Agricultural Research and Development, Jakarta, Selatan, DKI \\ Jakarta, Indonesia.
}

*Corresponding author: taniajune@apps.ipb.ac.id

Submitted final draft: 7 October $2020 \quad$ Accepted: 8 February 2021

http://doi.org/10.46754/jssm.2021.10.024

\begin{abstract}
Coffee production has been substantial to the Indonesian economy. The increase in both domestic and global coffee consumption provides the opportunity for a rise in income of coffee farmers. However, the Indonesian coffee production system is facing many challenges, which include low productivity, high fluctuation in production, social, economic and environmental issues. These challenges are attributed to climate change and variability. To harness sustainable coffee production, these challenges should be overcome. In this review, the current status and challenges faced in Indonesian coffee production will be highlighted, while emphasising the impact of climate change and variability, and possible solutions to these challenges will be proposed, i.e. the implementation of climate-smart agriculture (CSA) in the Indonesian coffee production system. The majority of coffee producers in Indonesia are unable to reach optimal production because of very low fertilisation doses, traditional cultivation, which is compounded by the use of local clones characterised by low productivity, and the impact of climate variability. The major economic challenge was identified to be a lack of financial access to formal credit, while the major social challenge was low farmer capability. The complex and diverse challenges of coffee production require approaches that integrate environmental, economic, and social challenges. Implementing CSA in the coffee production system in Indonesia seems to be the most appropriate approach to address these challenges since it can synergise increasing productivity and farmers' income, implementing adaptation and mitigation of climate change and increase farmer capability and credit access.
\end{abstract}

Keywords: Productivity, sustainability, climate change, climate variability.

\section{Introduction}

Coffee is one of Indonesian's main agricultural commodities. Currently, Indonesia is the thirdlargest coffee producer and exporter in the world. In 2018, Indonesian coffee plantation covered a total area of approximately 1,241 million hectares, involving 896.932 million hectares (75.4\%) of Robusta (Coffea canephora) plantations involving 1.23 million farmers, and 354.582 million hectares $(24.6 \%)$ of Arabica (Coffea arabica) plantations involving 542,027 farmers (Directorate of Plantation, 2019). More than $90 \%$ of total plantations are cultivated by smallholder farmers who own relatively small plantations of about 1-2 hectares (Byrareddy, Kouadio, Mushtaq, \& Stone, 2019).

Indonesian per capita consumption is rising rapidly. In 2013, the amount of Indonesian coffee consumption per capita was $1 \mathrm{~kg} /$ capita/ year (AEKI, 2019), with the current domestic consumption rate of $8 \%$ per year (IDH, 2014), while the global consumption rate is $2.01 \%$ per year (ICO, 2017). Increasing consumption rate and demand provide an opportunity for coffee farmers in Indonesia. Moreover, the development of coffee production also provides more benefits for economic development as a source of the country's stock exchange, regional 
development, agribusiness and agro-industry drivers, an increase in employment rate, and poverty alleviation. In addition to economic and social benefit, coffee plantations also provide benefits for environmental conservation, especially shaded coffee farm (Supriadi, 2015; Supriadi \& Pranowo, 2016; Hayyun et al., 2018; Iskandar \& Partasasmita, 2018 ).

To exploit the opportunities mentioned above, the coffee production system in Indonesia is facing various challenges, including low productivity, high fluctuation of annual production, declining productivity trend, environmental degradation, and other socioeconomic problems. The Indonesian smallholder coffee productivity and quality levels are low, according to international standards, which calls for the need to boost productivity in the sector (Wahyudi \& Jati, 2012; Sarirahayu \& Aprianingsih, 2018) both in consuming and producing countries to implement sustainability program. This paper describes the result of a study to evaluate the challenges of sustainability coffee certification in Indonesia. Coffee producers in Indonesia mainly are smallholders with relatively low income, low education and skill. Number of problems in the production of coffee bean such as low productivity, unstable price and increase in consumers' requirement bring them into a dilemma that they shall continue to produce coffee, but they also have to stand in the risk of poverty. Sustainability program which is lead to certification to show that the farm and its supply chain confirmed with certain requirement resulting a big question mark, whether producer can get benefit from the program such as getting incentive price (premium). The significant year-to-year fluctuation in coffee productivity threatens the livelihood of coffee farmers. During the periods of low productivity, consistent and adequate earnings of most farmers are not secured by the coffee production.

Consequently, farmers do not have sufficient funds to finance the adoption and application of more enhanced technology for their farming practices. Some of the problems faced by coffee productions in Indonesia have drawn coffee farmers into a dilemma of whether they can continue to produce coffee or shift their crops (Wahyudi \& Jati, 2012) both in consuming and producing countries to implement sustainability program. This paper describes the result of a study to evaluate the challenges of sustainability coffee certification in Indonesia. Coffee producers in Indonesia mainly are smallholders with relatively low income, low education and skill. Number of problems in the production of coffee bean such as low productivity, unstable price and increase in consumers' requirement bring them into a dilemma that they shall continue to produce coffee, but they also have to stand in the risk of poverty. Sustainability program which is lead to certification to show that the farm and its supply chain confirmed with certain requirement resulting a big question mark, whether producer can get benefit from the program such as getting incentive price (premium). This dilemma serves as a serious issue for the sustainability of the country's coffee production.

The challenges encountered in coffee production are further compounded by the impact of climate variability and change. Climate change and variability have led to declining and fluctuations in the coffee production trends (Camargo, 2010; Zullo et al., 2011; Chengappa \& Devika, 2017; Syakir \& Surmaini, 2017; Pham et al., 2019). Coffee, being a perennial crop, is very sensitive to climate conditions, and most of the coffee species are cultivated on rain-fed areas that are more susceptible to climate variability (Gunathilaka et al., 2018). Some climate variability that influence coffee production are rainfall intensity and distribution, temperature and dry periods (Coffee \& Climate, 2015). Cultivation activities need to be adjusted to climate variability to achieve potential productivity.

In the future, climate change will serve as the main obstacle to the development of coffee due to the extreme sensitivity of coffee plants to climatic conditions and has a long lifespan. Therefore, appropriate strategies should be 
developed to ensure the adaptability of the coffee plants since shifting the crop is associated with high upfront capital costs. The climate change and variability impose complex issues for the development of coffee in Indonesia, and especially considering that $90 \%$ of Indonesian coffee farmers are smallholder farmers whose capacity to deal with the effects of climate change is significantly low (Directorate of Plantation, 2019).

Numerous options and measures to achieve adaptability of coffee have been identified. Jowever, the adoption level of the technologies at the farm level is still very low (Yuliasmara, 2016; Syakir \& Surmaini, 2017). It is exacerbated by the limited access of most farmers to climate information, markets, technology, credit, and climate risk management information. Policymakers, stakeholders, and farmers should enforce the accelerated adaptation process because the challenges of climate change will continue to exist. One comprehensive acceleration effort is through the development of climate-smart agriculture (CSA) for the coffee production system. CSA encourages the development of sustainable farming systems through farming practices and approaches to increase productivity and income, increase farmers' adaptation capacity, and develop low emissions farming systems to cope with climate change (FAO, 2013a). In contrast to conventional farming systems, CSA integrates climate change into the farming system, especially in seeking synergy to integrate adaptation and mitigation efforts (Campbell et al., 2014; Lipper et al., 2014; Thornton et al., 2018).

This paper provides an overview of the challenges and barriers of the coffee production system in Indonesia, the impact of climate variability and climate change on coffee production and explores the need to promote CSA-based coffee production systems in Indonesia as an approach to develop more sustainable coffee production systems.

\section{Coffee Production Challenges in Indonesia}

\section{Low Productivity}

The main challenge of coffee production in Indonesia is low productivity. The national average stood at only $677 \mathrm{~kg} /$ ha for Robusta and $774 \mathrm{~kg} / \mathrm{ha}$ for Arabica (Directorate of Plantation, 2019), while the potential productivity for Robusta is $1600-3700 \mathrm{~kg} /$ ha and for Arabica is $1800 \mathrm{~kg} / \mathrm{ha}$ (Prastowo et al., 2010). The current productivity is only $60 \%$ of the potential production (Wahyudi \& Jati, 2012). This productivity is far below Brazil's and Vietnam's coffee productivity, which ranges between 1.52.5 tonnes/ha (Figure1). Productivity remained low due to environmental, socio-economic factors, institutional, and farm management challenges. For instance, most of the coffee production in Indonesia is still traditionally cultivated, characterised by the use of local clones that have low productivity and not intensively managed (Hafif et al., 2013).

Furthermore, very low fertilisation doses to not fertilise coffee plants contribute to the incapability of the majority of coffee farmers in Indonesia to reach optimal production levels. For instance, coffee farmers in Indonesia applied Nitrogen fertiliser with doses 4 of 4-93 $\mathrm{kg} / \mathrm{ha}$, while recommendation doses is 135 $\mathrm{kg} / \mathrm{ha}$. (Byrareddy et al., 2019). In addition to the described challenges, climate factors also contribute to Indonesia's low coffee productivity (Neilson, 2013). The cultivation activities need to be adjusted to climate variability to boost coffee productivity.

\section{Social and Economic Challenges}

The economic challenges of low productivity result in low income for coffee farmers. The high fluctuations of annual production have a very significant impact on the income of coffee farmers, whose livelihood relies only on coffee farming (monoculture farmer). There are 96\% of smallholder coffee farmers who cultivated coffee as a monoculture farm (Wahyudi \& Jati, 2012). These monoculture farmers are economically more vulnerable to production 


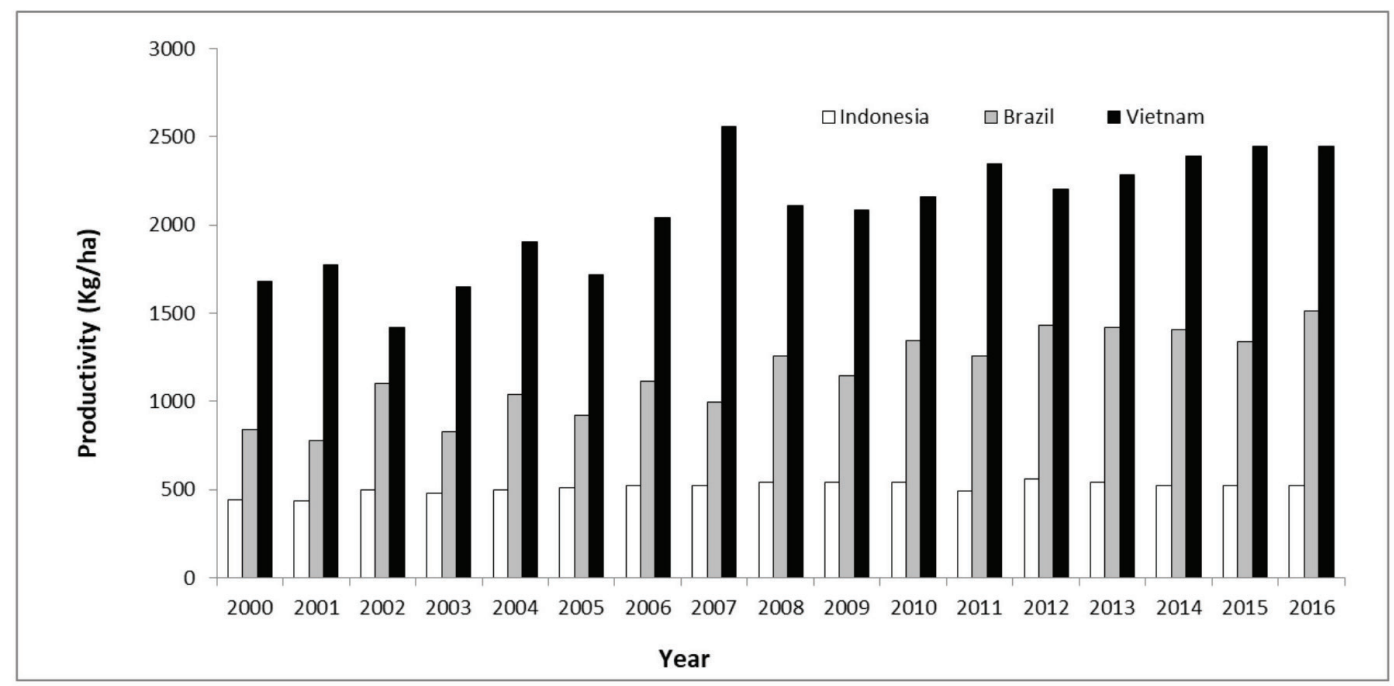

Figure 1: Indonesian coffee productivity among major competitor countries (Data source: FAOSTAT)

dynamics and climate change (Altieri et al., 2015). As a result, coffee is not perceived as a lucrative plantation.

A lack of access to financial services is another major economic challenge facing coffee farmers (Sartika \& Karyani, 2018). Access to improved management and technology application requires high input cost, which prevents coffee farmers from accessing the services and remaining as victims of low productivity. This aspect reveals that to boost coffee productivity, not only does it require technical support, but also attention on the social and economic aspects. The accessibility to the formal sources of credit has proven to be effective in contributing towards the increase of coffee farmers' income in Aceh Province (Iski \& Kusnadi, 2016).

Different social and institutional constraints also disrupt coffee production efficiency. These constraints include a lack of education regarding to the field of work, resulting in inadequate knowledge and skills necessary for effective and efficient agricultural techniques (Sartika \& Karyani, 2018). Agricultural extension services play an important role through knowledge and information access to strengthen farmers' capacity and knowledge in CSA (Olorunfemi
\& Oladele, 2019)the role of extension agents in scaling up the utilization of Climate Smart Agricultural Initiatives (CSAI). However, nowadays, the performance of extension institutions in Indonesia tends to decrease. Decentralisation, which has been implemented since 1999, has proven to be disastrous for agriculture extension institutions. The existence of this institution has been marginalised at the district and provincial levels. It caused a weakening of extension capacity and influence of agriculture performance (Listiana et al., 2018).

Coffee farmers across Indonesia do not have access to a reliable extension system (Neilson, 2013). The weakening extension role in the transfer of agriculture technology to farmers causes low levels of technology adoption. This incapability of farmers to adopt good agronomic management and practices, such as mulching, pruning, fertilising, and irrigation, has threatened coffee productivity.

\section{Environmental Challenges}

Coffee plantations in Indonesia are mostly located in communal, rain-fed, and mountainous areas. Hafif et al. (2013) revealed that coffee plantations in Indonesia, particularly in 
Lampung province, which is a major province for coffee production in Indonesia, are cultivated in acidic and dry soils. Soil acidification is a potentially serious issue of concern regarding land degradation. In the absence of proper soil treatment, soil acidification can have a major impact on agricultural productivity and sustainable farming systems.

Coffee grown in marginal bioclimatic conditions is more vulnerable to environmental stressors, particular stressors imposed by climate variability and change (Damatta \& Ramalho, 2006). As a climate-sensitive perennial crop, climate variability and climate change are likely to be the main environmental issues in coffee production (Craparo et al., 2015). Therefore, assessment and identification, the extent of the climate-driven impact on coffee production, will be of vital importance to improve coffee productivity and the sustainability of coffee production in Indonesia.

\section{The Impact of Climate Variability and Change on Coffee Production}

\section{The Impact of Climate Variability}

Climate variability is a major determinant of plant growth and development (Leng et al., 2016). Also, climate factors affect almost onethird of variability of agricultural production (Ray et al., 2015) and crop productivity is strongly influenced by global climate oscillations in almost two-thirds of the world's agricultural regions (Heino et al., 2019).

Several studies on the impact of climate variability on coffee production were reported by Tucker et al. (2010), Akinseye \& Vincent (2013), Jayakumar \& Rajavel (2017) Dula (2018) and Pham et al. (2019). These studies reported that climate variability have a direct influence on coffee production, pest, disease and drought, while rainfall intensity, rainfall distribution and temperature are climate variables that affect coffee production systems.

Analysing the spatial and temporal climate variability on coffee production may reveal the different aspects of climate factors, which include how they affect production, extension, and assessing their potential economic loss. This information is essential for adaptation strategy planning.

Many adaptation strategies and options for coffee production have been revealed in literature. However, most of these approaches did not clearly show the quantitative measure of the extent to which they can minimise the impacts of climate variability (Pham et al., 2019). The different climate adaptation options for the coffee production system include the tree and shade system, integrated pest management, diversifying system, soil and water conservation at the plantation level, and forest conservation (Verburg et al., 2019). The cultivation calendar is one of the adaptation options to climate variability that has the potential to produce results if applied to coffee production. A cultivation calendar provides information on cultivation activities based on climate conditions. The cultivation calendar for one year of production can facilitate and assist farmers in applying effective agronomic practices. But to date, the cultivation calendar for coffee production in Indonesia is not yet available. The development of this calendar has the potential to significantly increase productivity and maintain production stability throughout the production season since this calendar considers climate variability.

Climate variability in Indonesia is mostly influenced by the monsoon season (intra-annual factor), El-Nino southern oscillations (ENSO) (Aldrian\&Susanto,2003;Arrigo \&Wilson,2008) and the Indian Ocean Dipole (IOD) (Mulyana, 2002; Arrigo \& Wilson, 2008; Hendrawan et al., 2019). ENSO is one of the climate variability indicators that have been studied intensively in Indonesia, particularly on the influence of ENSO on agricultural production (Arrigo \& Wilson, 2008; Heino et al., 2018). Information on the influence and impact of inter-annual climate indicators, such as ENSO and IOD, on coffee production provides relative assistance towards effective decision-making processes in activities necessary for high productivity, based on ENSO/IOD predictions. In the production of 
rice, a seasonal crop, the consistent information on ENSO was used in management strategy, and this approach significantly benefited farmers (Boer \& Surmaini, 2019).

The influence of ENSO on coffee production in Indonesia was reported by Supriadi (2015), Fitria Yuliasmara (2017), and Syakir \& Surmaini (2017). El Nino events were reported to have an effect on coffee production in East Java. During that season, a drop of $5-20 \%$ in coffee production was reported. Adverse effects of El Nino were also reported in other countries, such as India (Jayakumar et al., 2017) and Colombia (Bastianin et al., 2018). In Columbia, ENSO influenced not only coffee products, but also the prices of the commodity.

Climate variability also causes a shift in coffee phenology (Workie \& Debella, 2018). Understanding the impact of climate variability on the coffee phenology shift in main production areas could be useful in developing a dynamic coffee calendar based on climate forecast. The adjustments in cultivation activities are anticipated to reduce fluctuations in annual production.

\section{The Impact of Climate Change}

The impact of climate change on coffee production include the decline of coffee production (Camargo, 2010; Davis et al., 2012; Jaramillo et al., 2013; Iscaro, 2014; Craparo et al., 2015; Läderach et al., 2017), decrease in the quality of coffee (Läderach et al., 2017), increased pest and disease outbreak and distribution (Jaramillo et al., 2011; Avelino et al., 2015; Magrach \& Ghazoul, 2015; Groenen, 2018) and changes in climate suitability. Numerous studies on climate suitability for coffee in coffee-producing countries have been conducted in Indonesia (Schroth et al., 2015), Nicaragua and Mexico (Läderach et al., 2017), Ethiopia (Davis et al., 2012; Moat et al., 2017), Nepal (Ranjitkar et al., 2016), Latin America (Imbach et al., 2017), Uganda and Tanzania (Rahn et al., 2018), East Africa (Jaramillo et al., 2013), Puerto Rico (Fain et al., 2018) and globally (Bunn et al., 2015; Ovalle-rivera et al., 2015). These studies revealed that in the future (2050), the projected area suitable for coffee plantations would be reduced. Furthermore, the impact of climate change on the economic and social vulnerabilities of coffee farmers is also anticipated to increase.

Most of studies on the impact of variability and climate change on coffee production have been conducted in Latin America for Arabica, while studies for Robusta in Southeast Asia with special emphasis on Indonesia and Vietnam is still limited (Pham et al., 2019).

The historical data on coffee productivity in Indonesia for the period 1961-2015 is shown in Figure 2. In summary, Figure 2 shows that coffee productivity in Indonesia tends to decline as time progresses. Yet, there is no comprehensive study discussing the main cause of declining productivity. Qualitatively, Sujatmiko and Ihsaniyati (2018) reported that climate change is the main cause of the decline in productivity. To the best of our knowledge, no studies have

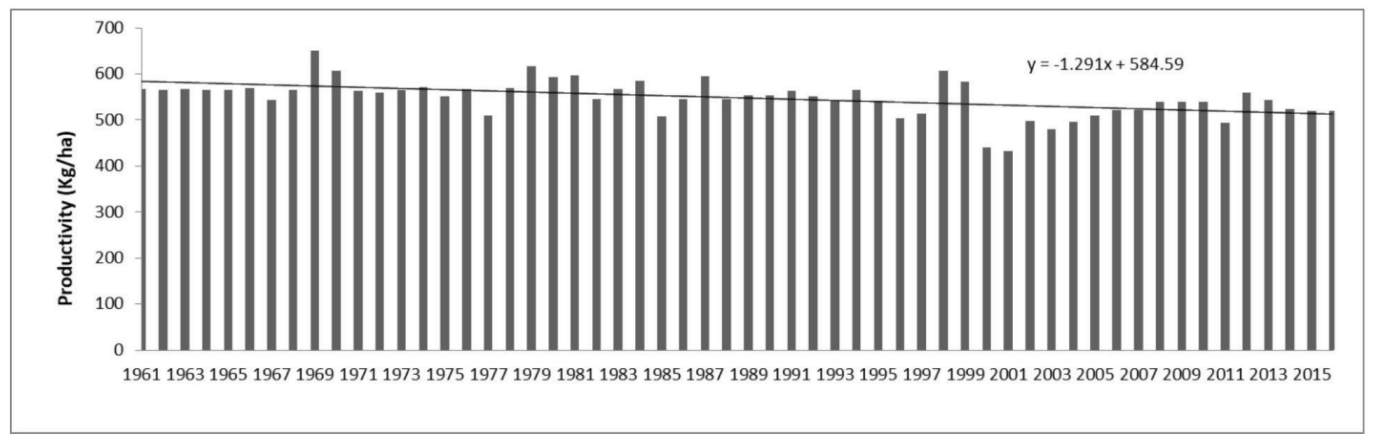

Figure 2: National coffee productivity of Indonesia for the period 1961-2015

(Source: FAOSTAT) 
yet to quantitatively investigated the impact of climate change on coffee production in Indonesia. Contrary to the findings of the previous research, Rosiana, (2019) attributed the decline in productivity to the age or period the coffee trees were cultivated in plantations, which was more than 25 years.

Coffee is a perennial crop with a long lifespan. Therefore, the projections of climate suitability of coffee plantation would assist in selecting a new plantation area for future coffee development. The future sustainable development of coffee production should consider information on climate suitability to reduce yield losses due to climate stress. This information is also very important for the preparation of other adaptation strategies, such as the direction of developing varieties, etc. Climate suitability of the coffee areas can also affect the sustainability of the Indonesian coffee production system in the future.

\section{CSA for Sustainable Coffee Production}

Many studies attest that various coffee production challenges are attributed to climate variability and climate change. These challenges need immediate attention to reduce the risk of coffee production sustainability being threatened. Thus, the assessment of the sustainability or status of coffee production should be of major concern. In Indonesia, the sustainability assessment mostly focus on the supply chain of the commodity (Neilson, 2008, 2013; Astuti et al., 2012; Arifin, 2014; Jaya et al., 2014; Jaya et al., 2014; Astuti et al, 2020), while the assessment of sustainability production system is still limited. Coffee production systems must be transformed towards a system that is able to increase in productivity, be able to adapt to variability and climate change, and not cause a negative impact on the environment.

CSA is an approach proposed by FAO in 2010 to build the main pillar as follows: 1) increasing productivity and income, 2 ) adapting and building climate change resilience, and 3) reducing or even removing emissions of greenhouse gas relative to conventional practices (FAO, 2013a). To achieve the three main pillars, CSA integrates economic, social, and environmental dimensions of sustainable farming system through a farming practice approach. In contrast to conventional farming systems, CSA integrates climate change in farming systems, specifically seeking out opportunities to integrate adaptation and mitigation efforts (Lipper et al., 2014).

Increasing coffee production through the expansion of new coffee land is no longer economically and environmentally possible. Then, it is necessary to transform the coffee production system. CSA is proposed as an approach for transforming and reorienting the production system in response to climate risks (Nyasimi et al., 2014). CSA is not a new technology, but rather an approach for integrating various interventions across production systems, landscapes, supply chains, regulations, and policies (Lipper et al., 2014). CSA emphasises prioritisation of a range of technology options on the locally suited production system and the range of CSA intervention is wide, including soil, water management, protection, carbon, financial support and building capacity.

Torquebiau et al. (2018) mention that the success of CSA requires innovative policies, practices, and financial support, and it needs interdisciplinary research. The main challenges involved in implementing CSA are identification of the situation, economic valuation, setting technological priorities, and models for investment (Andrieu et al., 2017; Thornton et al., 2018) resulting in more frequent dry years. The national economy is vulnerable to climate change due to $50 \%$ of the gross domestic product coming from the agricultural sector and $75 \%$ of the population living in rural areas. The Climate-Smart Agriculture (CSA). Some of the methods and approaches that have been used to develop priority strategies in CSA include cost-benefit analysis (CBA) (Campbell et al., 2014; Andrieu et al., 2017), participatory (Khatri-Chhetri, 2017; Mwongera et al., 2017; Andrieu et al., 2019 Khatri-Chhetri et al., 
2019), life-cycle assessment (Acosta-Alba et al., 2019; Andrieu et al., 2019), and multi-criterion decision-making and analytical hierarchy processes (Brandt et al., 2017).

Since FAO introduced it in 2010, CSA has been widely implemented, especially in the food crops subsector. Khatri-Chhetri et al. (2016) reported that CSA in rice farming in India provided greater profits. Empirical evidence shows that the implementation of CSA can increase rice productivity. Implementation of CSA for annual cocoa crop production in Ghana was shown by Akrofi-Atitianti et al. (2018), in which CSA practitioners gained $29 \%$ higher income per ha of cocoa compared with the conventional production system. Environmentally, CSA was proven to have a positive impact on greenhouse gas mitigation. Other success stories of CSA implementation have been documented, for instance, by FAO (2013b) and Nyasimi et al. (2014).

CSA for sustainable coffee production requires study and assessment to select technology priorities. Brounen et al. (2019) implemented CSA in coffee production as a series of technology practices, that include (i) increased density of coffee trees, (ii) climate resilient varieties, (iii) better soil management, (iv) optimised shading, and (v) improved wastewater management. Therefore, implementing CSA in Indonesian coffee production system needs further studies.

\section{Potential and Challenges of Implementing CSA in Indonesian Coffee Production System}

There is an approximately a $40 \%$ coffee productivity gap in Indonesia. Various research on how to increase coffee productivity have been conducted. Yet the proposed strategies seem like a partial approach. Sarirahayu and Aprianingsih (2018) conveyed some strategies to improve coffee productivity, including fair trade certification, increasing technology adoption and intensive farmer training. The technological and financial aspects were not considered in this strategy. The discussion above has shown that climate variability and change are environmental challenges leading to low coffee productivity, unstable production and declining productivity. An efficient technical approach is required to develop proper strategies for climate variability and change. Furthermore, the production challenge was reported to be hampered by economic and social issues. The major economic issue is formal financial support, while the social aspect is concerned with how to increase farmer capability. As CSA presents itself as a holistic strategy, this approach seems to be appropriate to improve the coffee production system in Indonesia.

Various adaptation options and measurements to climate change and variability have been identified (Table 1). This option is divided into three groups, including land conservation, water conservation, and crop conservation (Supriadi, 2015). Unfortunately, the adaptation options that use climate and weather information do not exist yet. Climate and weather forecasting has become crucial for cultivation decision-making due to the increasing climate variability as an impact of climate change.

Most of the coffee production in Indonesia comes from smallholder farming, which encompasses a wide range of bioclimatic and geographical varieties and diverse cultivation methods. Therefore, to improve coffee productivity, it requires site-specific strategies. CSA emphasises prioritisation of a range of technological options on a locally suited production system.

Coffee plantations also have a great opportunity to play a key role in carbon sequestration by implementing a coffee-based agroforestry system. Supriadi and Pranowo (2016) found that a farmer has practiced a coffeebased agroforestry system in various regions in Indonesia. Coffee-based agroforestry systems provide several benefits namely (1) land and water conservation, and biodiversity, (2) addition of soil nutrients, (3) control of microclimate, (4) carbon sequestration, (5) suppression of pests and diseases, and (6) increase in farmer income. 
Table 1: Various adaptation and measurements of climate change and variability

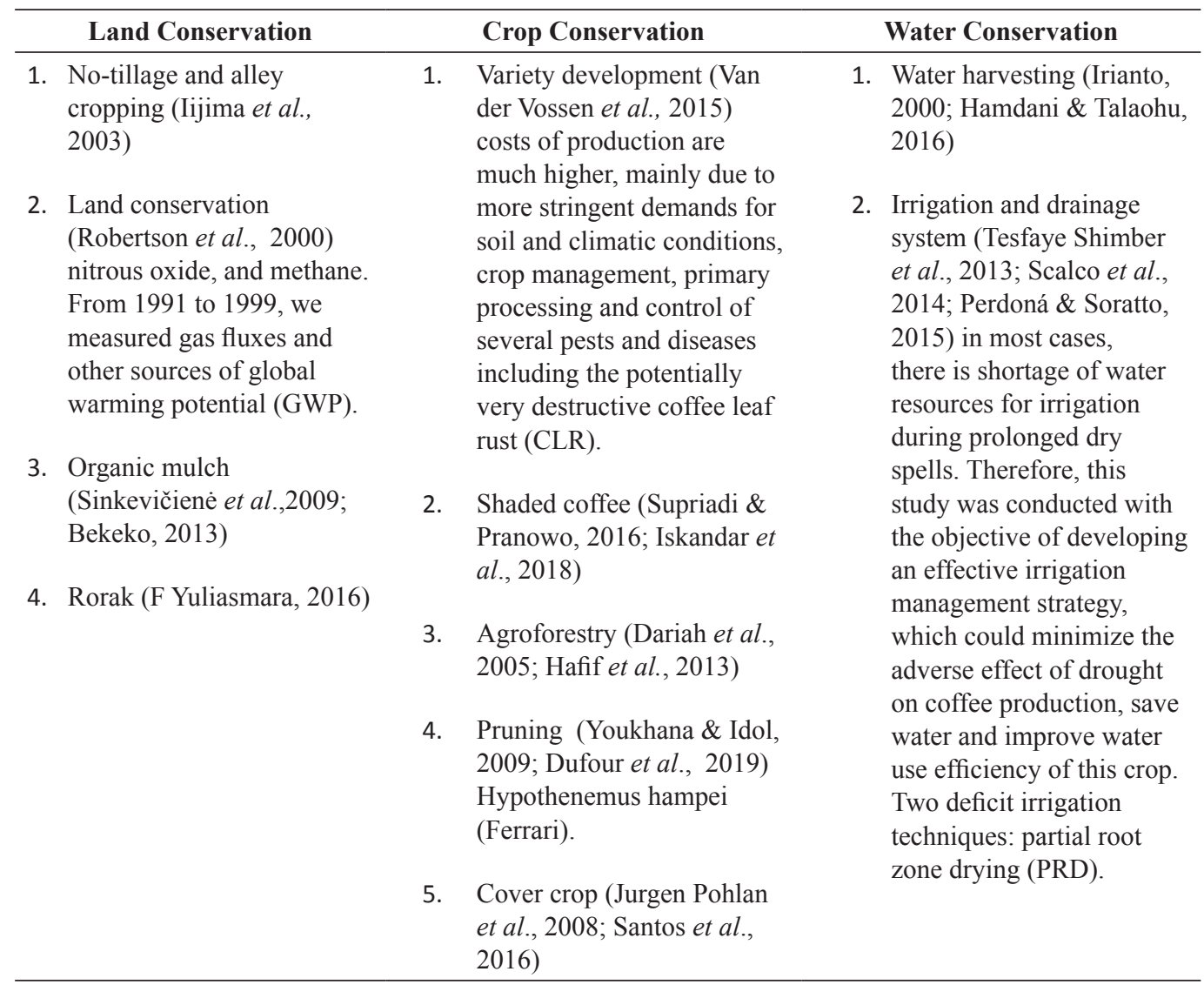

Nowadays, programmes and efforts to reduce emissions are of great concern to the government and scientists. Hence, CSA should be considered for implementation in coffee production. Research on the development of CSA-based coffee production systems has become very important and strategic in maintaining the sustainability of coffee production in Indonesia.

The success of CSA will be largely determined by the information obtained from the ground or grassroots level of coffee production, i.e. in the field. Therefore, the implementation of CSA in the coffee production system requires identification of the situation and the condition of the system, which include biophysics, social and economic aspects (Thornton et al., 2018). The impact of climate variability and change on a coffee production system should be identified at a farming level, i.e. in coffee plantations. These kinds of studies, in coffee plantations, are still lacking in Indonesia. The availability of data, coupled with the quality of agronomic and biophysics data, could influence agroclimatology research in Indonesia.

The improvement of farmers' capability and knowledge is still constrained by the unclear existence of agricultural extension institutions. Local governments should put effort and invest in developing and improving the extension role in agriculture development. Moreover, the capacity of extension workers must be improved, specifically on specific climate and weather and how they can be applied to agronomic practices. Most of the agricultural extension services in Indonesia focus on food crops, while there is 
less concern for horticulture and plantation crops. Agricultural extension officers in the main coffee plantation area should also have specific and adequate knowledge of main coffee production.

Prioritising practices present a special challenge to CSA, including what climate-smart related to practices and technology and CSA technology need to be assessed regarding the three main pillars (productivity, adaptation and mitigation). Decision-making processes will be crucial to identifying technologies, practices and policies.

CSA must be developed with a pilot project. Farmers will learn more quickly by being in direct contact with the technologies as they are conducting farming practices. The development of this pilot project requires funding and policy support from the government.

\section{Conclusion}

The main challenges involved in coffee production in Indonesia are low productivity with high production fluctuation, climate variability and climate change, low capital and credit access, and low capacity of farmers. The complexity and diversity of coffee production challenges require site-specific approach. Applying CSA on the coffee production system Indonesia appears to be the most appropriate approach to address the challenges since it pays attention to increasing productivity and income, as well as adaptation and mitigation measures. Moreover, CSA integrates economic, social and environmental dimensions of sustainable farming systems.

The application of CSA in the development of coffee production systems in Indonesia faces several challenges, including the limited studies on climate variability and climate change impact on coffee production in Indonesia, extension services issues, quantity and quality of data, policy, financial support and coordination among research institutions, local governments, and extension institutions. Therefore, in-depth research on climate change and its diverse impacts needs to be conducted. Prioritising CSA practices in the main coffee plantation area needs to be assessed by involving all related stakeholders, namely farmers, agricultural extensions, research institutions, local governments, and the private sector.

\section{Acknowledgements}

The authors extend their gratitude to reviewers for critical comments on the manuscript and the university for the research opportunity.

\section{References}

Acosta-Alba, I., Chia, E., \& Andrieu, N. (2019). The LCA4CSA framework: Using life cycle assessment to strengthen environmental sustainability analysis of climate smart agriculture options at farm and crop system levels. Agricultural Systems, 171(May 2018), 155-170. https://doi.org/10.1016/j. agsy.2019.02.001

AEKI. (2019). Konsumsi kopi dalam negeri alami pertumbuhan hingga 8 persen setiap tahun. Bisnis.Com. https://ekonomi. bisnis.com/read/20190717/99/1125329/ konsumsi-kopi-dalam-negeri-alamipertumbuhan-hingga-8-persen-setiap-tahun

Akinseye, F. M., \& Vincent, A. (2013). Assessing the impacts of climate variability on crop yield over Sudano- Sahelian zone in Nigeria. Access International Journal of Agricultural Sciences, 1(7), 91-98.

Akrofi-Atitianti, F., Ifejika Speranza, C., Bockel, L., \& Asare, R. (2018). Assessing climate smart agriculture and its determinants of practice in ghana: A case of the cocoa production system. Land, 7(1), 1-30. https:// doi.org/10.3390/land7010030

Aldrian, E., \& Susanto, D. R. (2003). Identification of three dominant rainfall regions within Indonesia and their relationship to sea surface temperature. International Journal of Climatology, 23(12), 1435-1452. 
Altieri, M. A., Nicholls, C. I., Henao, A., \& Lana, M. A. (2015). Agroecology and the design of climate change-resilient farming systems. Agronomy for Sustainable Development, 35(3), 869-890. https://doi. org/10.1007/s13593-015-0285-2

Andrieu, N, Sogoba, B., Zougmore, R., Howland, F., Samake, O., BonillaFindji, O., ... Corner-Dolloff, C. (2017). Prioritizing investments for climate-smart agriculture: Lessons learned from Mali. Agricultural Systems, 154, 13-24. https:// doi.org/10.1016/j.agsy.2017.02.008

Andrieu, Nadine, Howland, F., Acosta-Alba, I., Le Coq, J.-F., Osorio-Garcia, A. M., Martinez-Baron, D., ... Chia, E. (2019). Co-designing climate-smart farming systems with local stakeholders: A methodological framework for achieving large-scale change. Frontiers in Sustainable Food Systems, 3(37), 1-19. https://doi. org/10.3389/fsufs.2019.00037

Arifin, B. (2014). Global sustainability regulation and coffee supply chains in Lampung Province, Indonesia. Asian Journal of Agriculture and Development, 7(2), 67-89.

Arrigo, R. D., \& Wilson, R. (2008). El nino and indian ocean influences on Indonesian drought: Implication for forecasting rainfall and crop productivity. International Journal of Climatology, 28, 611-616. https://doi. org/10.1002/joc

Astuti, E. S., Offermans, A., \& Glasbergen, P. (2020). Sustainability certification and economic performance an analysis of coffee marketing channels in Indonesia. Journal of Economics and Sustainable Development, 6(24), 84-98.

Astuti, E. S., Offermans, \& Cörvers, R. (2012). The impact of coffee certification on the economic performance of Indonesian actors. Asian Journal of Agriculture and Development, 12(2), 1-13.

Avelino, J., Cristancho, M., Georgiou, S., Imbach, P., Aguilar, L., Bornemann, G.,
... Hruska, A. J. (2015). The coffee rust crises in Colombia and Central America ( 2008 - 2013 ): Impacts, plausible causes and proposed solutions. Food Security, 7, 303-321. https://doi.org/10.1007/s12571015-0446-9

Bastianin, A., Lanza, A., \& Manera, M. (2018). Economic impacts of El Nino Southern Oscillation: Evidence from the Colombian coffee market Andrea. Munich Personal RePEc Archive, (89984), 1-4.

Bekeko, Z. (2013). Effect of maize stover application as soil mulch on yield of arabica coffee (coffee arabica 1., rubiaceae) at Western Hararghe zone, Eastern Ethiopia. Sustainable Agriculture Research, 2(3), 15. https://doi.org/10.5539/sar.v2n3p15

Boer, R., \& Surmaini, E. (2019). Economic benefits of ENSO information in crop management decisions: Case study of rice farming in West Java, Indonesia. Theoretical and Applied Climatology. https://doi.org/10.1007/s00704-019-030559

Brandt, P., Kvakić, M., Butterbach-Bahl, K., \& Rufino, M. C. (2017). How to target climate-smart agriculture? Concept and application of the consensus-driven decision support framework "targetCSA." Agricultural Systems, 151, 234-245. https:// doi.org/10.1016/j.agsy.2015.12.011

Brounen, J., de Groot Ruiz, A., Isaza, C., van Keeken, R., \& Varoucha, E. (2019). The true price of climate-smart coffee: Quantifying the potential impact of climate-smart agriculture for Colombian coffee. Retrieved from https://trueprice.org/consumer/coffeesolidaridad-colombia/

Bunn, C., Läderach, P., Rivera, O. O., \& Kirschke, D. (2015). A bitter cup: Climate change profile of global production of Arabica and Robusta coffee. Climatic Change, 129, 89101. https://doi.org/10.1007/s10584-014$1306-x$

Byrareddy, V., Kouadio, L., Mushtaq, S., \& Stone, R. (2019). Sustainable production 
of robusta coffee under a changing climate: A 10-year monitoring of fertilizer management in coffee farms in Vietnam and Indonesia. Agronomi, 9(499), 1-19.

Camargo, M. B. P. (2010). The impact of climate variability and climate change on arabic coffee crop in Brazil. Bragantia, 69(1), 239-247.

Campbell, B. M., Thornton, P., Zougmoré, R., van Asten, P., \& Lipper, L. (2014). Sustainable intensification: What is its role in climate smart agriculture? Current Opinion in Environmental Sustainability, 8, 39-43. https://doi.org/10.1016/j. cosust.2014.07.002

Chengappa, P. G., \& Devika, C. M. (2017). Climate variability concerns for the future of coffee in India: An exploratory study. International Journal of Environmental, Agriculture and Biotechnology, 1(4), 819826. https://doi.org/10.22161/ijeab/1.4.27

Coffee \& climate (c\&c). (2015). Climate change adaptation in coffee production (January 20). Germany: Coffee \& climate.

Craparo, A. C. W., Asten, P. J. A. Van, Läderach, P., Jassogne, L. T. P., \& Grab, S. W. (2015). Coffea arabica yields decline in Tanzania due to climate change: Global implications. Agricultural and Forest Meteorology Journal, 207, 1-10.

Damatta, F. M., \& Ramalho, J. D. C. (2006). Impacts of drought and temperature stress on coffee physiology and production: A review. Braz. J. Plant Physiol., 18(1), 5581.

Dariah, A., Agus, F., \& Maswar. (2005). Soil quality of the land under CoffeeBased Farming System (Case Study at Sumberjaya, West Lampung). Jurnal Tanah dan Iklim, (23), 48-57.

Davis, A. P., Gole, T. W., Baena, S., \& Moat, J. (2012). The impact of climate change on indigenous arabica coffee predicting future trends and identifying priorities. PLoS
ONE, 7(11), 10-14. https://doi.org/10.1371/ journal.pone.0047981

Directorate of plantation. (2019). Statistik perkebunan Indonesia 2017-2019: Kopi. Direktorat Jenderal Perkebunan Kementerian Pertanian, 96.

Dufour, B. P., Kerana, I. W., \& Ribeyre, F. (2019). Effect of coffee tree pruning on berry production and coffee berry borer infestation in the Toba Highlands (North Sumatra). Crop Protection, 122(November 2018), 151-158. https://doi.org/10.1016/j. cropro.2019.05.003

Dula, T. (2018). Climate variability and determinants of its adaptation strategies; The case of coffee (coffea arabica) producer farmers at abeshege woreda, ethiopia. Agricultural Research \& Technology, 7(3), 1-5. https://doi.org/10.19080/ ARTOAJ.2018.17.556028

Fain, S. J., Quiñones, M., Álvarez-berríos, N. L., \& Parés-ramos, I. K. (2018). Climate change and coffee: Assessing vulnerability by modeling future climate suitability in the Caribbean island of Puerto Rico. Climatic Change, 146, 175-186. https://doi. org/10.1007/s10584-017-1949-5

FAO. (2013a). Climate-Smart agriculture sourcebook. Roma: FAO.

FAO. (2013b). FAO success stories on climatesmart agriculture. In FAO. Roma: FAO.

Groenen, D. (2018). The effects of climate change on the pests and diseases of coffee crops in Mesoamerica. Journal of Climatology \& Weather Forecasting, 06(03). https://doi. org/10.4172/2332-2594.1000239

Gunathilaka, R. P. D., Smart, J. C. R., \& Fleming, C. M. (2018). Adaptation to climate change in perennial cropping systems: Options, barriers and policy implications. Environmental Science and Policy, 82, 108-116. https://doi.org/10.1016/j. envsci.2018.01.011

Hafif, B., Prastowo, B., \& Prawiradiputra, B. R. (2013). Pengembangan perkebunan kopi 
berbasis inovasi di lahan kering masam. Pengembangan Inovasi Pertanian, 6(1), 199-206.

Hamdani, A., \& Talaohu, S. H. (2016). Development of rainfall and runoff harvesting technology: Farming system analysis of water resources utilization. Jurnal Pengkajian dan Pengembangan Teknologi Pertanian, (1), 153-165.

Hayyun, D. A., Megantara, E. N., \& Tata, B. (2018). Kajian layanan ekosistem pada sistem agroforestri berbasis kopi di Desa Cisero , Garut Pada awalnya, Perum Perhutani yang merupakan Badan Usaha Milik tunggal melalui kebijakannya yang bersifat top down. Suprapto ( 2014 ) melibatkan masyarakat melalui po. Jurnal Pengelolaan Lingkungan Berkelanjutan, 2(3), 200-219.

Heino, M., Guillaume, J. H. A., Müller, C., Iizumi, T., \& Kummu, M. (2019). A multimodel analysis of teleconnected crop yield variability in a range of cropping systems. Earth Syst. Dynam. Discuss., (March), $1-25$.

Heino, M., Puma, M. J., Ward, P. J., Kummu, M., Gerten, D., Heck, V., \& Siebert, S. (2018). Two-thirds of global cropland area impacted by climate oscillations. Nature Communications, 9(1257), 1-10. https:// doi.org/10.1038/s41467-017-02071-5

Hendrawan, I. G., Asai, K., Triwahyuni, A., \& Lestari, D. V. (2019). The interanual rainfall variability in Indonesia corresponding to El Niño Southern Oscillation and Indian Ocean Dipole. Acta Oceanologica Sinica, 38(7), 57-66. https://doi.org/10.1007/ s13131-019-1457-1

ICO. (2017). Historical data on The Global Coffee Trade. http://www.ico.org/new historical.asp

IDH. (2014). Indonesia:A business case for sustainable coffee production. www. sustainablecoffeeprogram.com/site/getfile. php?id=377
Iijima, M., Izumi, Y., Yuliadi, E., Sunyoto, Afandi, \& Utomo, M. (2003). Erosion control on a steep sloped coffee field in Indonesia with alley cropping, intercropped vegetables, and no-tillage. Plant Production Science, 6(3), 224-229. https://doi. org/10.1626/pps.6.224

Imbach, P., Beardsley, M., Bouroncle, C., Medellin, C., Läderach, P., Hidalgo, H., ... Donatti, C. I. (2017). Climate change, ecosystems and smallholder agriculture in Central America: An introduction to the special issue. Climatic Change, 141(1), 1-12. https://doi.org/10.1007/s10584-017$1920-5$

Irianto, G. (2000). Rainfall-runoff harvesting for improving upland agriculture productivity and controlling floods and droughts. Berita Biologi, 5(April), 29-39.

Iscaro, J. (2014). The impact of climate change on coffee production in Colombia and Ethiopia. Global Majority E-Journal, 5(1), 33-43.

Iskandar, B. S., Iskandar, J., \& Partasasmita, R. (2018). Planting coffee and take care of forest: A case study on coffee cultivation in the forest carried out among people of Palintang, Highland of Bandung, West Java, Indonesia. Biodiversitas, 19(6), 2183-2195. https://doi.org/10.13057/biodiv/d190626

Iski, N., \& Kusnadi, N. (2016). Pengaruh kredit terhadap pendapatan petani kopi arabika di Kabupaten Aceh Tengah Provinsi Aceh. Jurnal Manajemen \& Agribisnis, 13(2), 132-144. https://doi.org/10.17358/ JMA.13.2.132

Jaramillo, J., Muchugu, E., Vega, F. E., Davis, A., Borgemeister, C., \& Chabi-olaye, A. (2011). Some like it hot: The influence and implications of climate change on coffee berry borer (hypothenemus hampei ) and coffee production in East Africa. PLoS ONE, 6(9). https://doi.org/10.1371/journal. pone. 0024528

Jaramillo, J., Setamou, M., Muchugu, E., Chabiolaye, A., Jaramillo, A., Mukabana, J., ... 
Borgemeister, C. (2013). Climate change or urbanization? Impacts on a traditional coffee production system in east africa over the last 80 years. PLoS ONE, 8(1). https:// doi.org/10.1371/journal.pone.0051815

Jaya, R., Machfud, M., Raharja, S., \& Marimin, M. (2014). Prediction of sustainable supply chain management for gayo coffee using system dynamic approach prediction of sustainable supply chain. Journal of Theoretical and Applied Information Technology, 70(2), 372-380.

Jaya, R., Mahfud, M., Raharja, S., \& Marimin, M. (2014). Sustainability analysis for gayo coffee supply chain. International Journal on Advanced Science, Engineering and Information Technology, 3(2), 24-28.

Jayakumar, M., \& Rajavel, M. (2017). Coffee yield forecasting using climate indices based agrometeorological model in Kerala. MAUSAM, 2(April), 309-316.

Jayakumar, M., Rajavel, M., \& Surendran, U. (2017). Impact of climate variability on coffee yield in India - with a micro-level case study using long-term coffee yield data of humid tropical Kerala. Climatic Change, $1-15$.

Jurgen Pohlan, H. A., Janssens, M. J. J., \& Eversbusch, B. G. (2008). Impact of canavalia cover crop management in coffea arabica 1. On plant-invertebrate associations. The Open Agriculture Journal, 2(1), 84-89. https://doi. org/10.2174/1874331500802010084

Khatri-Chhetri, A., Aggarwal, P. K., Joshi, P. K., \& Vyas, S. (2017). Farmers' prioritization of climate-smart agriculture (CSA) technologies. Agricultural Systems, 151, 184-191. https://doi.org/10.1016/j. agsy.2016.10.005

Khatri-Chhetri, A., Aryal, J. P., Sapkota, T. B., \& Khurana, R. (2016). Economic benefits of climate-smart agricultural practices to smallholder farmers in the Indo-Gangetic Plains of India. Current Science, 110(7),
1251-1256. https://doi.org/10.18520/cs/ v110/i7/1251-1256

Khatri-Chhetri, A., Pant, A., Aggarwal, P. K., Vasireddy, V. V., \& Yadav, A. (2019). Stakeholders prioritization of climate-smart agriculture interventions: Evaluation of a framework. Agricultural Systems, 174(June 2018), 23-31. https://doi.org/10.1016/j. agsy.2019.03.002

Läderach, P., Ramirez-Villegas, J., NavarroRacines, C., Zelaya, C., Martinez-Valle, A., \& Jarvis, A. (2017). Climate change adaptation of coffee production in space and time. Climatic Change, 141(1), 47-62. https://doi.org/10.1007/s10584-016-1788-9

Leng, G., Zhang, X., Huang, M., Asrar, G. R., \& Leung, L. R. (2016). The role of climate covariability on crop yields in the conterminous United States. Nature, 6(September), 1-11. https://doi. org/10.1038/srep33160

Lipper, L., Thornton, P., Campbell, B. M., Baedeker, T., Braimoh, A., Caron, P., ... Emmanuel, F. (2014). Climate-smart agriculture for food security C. Nature Climate Change, 4, 1068-1072. https://doi. org/10.1038/nclimate2437

Listiana, I., Sumardjo, Sadono, D., \& Tjiptopranoto, P. (2018). Hubungan kapasitas penyuluh dengan kepuasan petani dalam kegiatan penyuluhan. Jurnal Penyuluhan, 14(2), 244-256.

Magrach, A., \& Ghazoul, J. (2015). Climate and pest-driven geographic shifts in global coffee production: Implications for forest cover, biodiversity and carbon storage. PLoS ONE, 10(7), 1-15. https://doi. org/10.1371/journal.pone.0133071

Moat, J., Williams, J., Baena, S., Wilkinson, T., Gole, T. W., Challa, Z. K., ... Davis, A. P. (2017). Resilience potential of the Ethiopian coffee sector under climate change. Nature Plants, (June). https://doi.org/10.1038/ nplants.2017.81 
Mulyana, E. (2002). Pengaruh dipole mode terhadap curah hujan di Indonesia. Jurnal Sains \& Teknologi Modifikasi Cuaca, 3(1), $39-43$.

Mwongera, C., Shikuku, K. M., Twyman, J., Läderach, P., Ampaire, E., Van Asten, P., ... Winowiecki, L. A. (2017). Climate smart agriculture rapid appraisal (CSARA): A tool for prioritizing context-specific climate smart agriculture technologies. Agricultural Systems, 151, 192-203. https:// doi.org/10.1016/j.agsy.2016.05.009

Neilson, J. (2008). Global private regulation and value-chain restructuring in Indonesian smallholder coffee systems. World Development, 36(9), 1607-1622. https:// doi.org/10.1016/j.worlddev.2007.09.005

Neilson, J. (2013). The value chain for Indonesian coffee in a green economy. Buletin RISTRI, 4(3), 183-198.

Nyasimi, M., Amwata, D., Hove, L., Kinyangi, J., \& Wamukoya, G. (2014). Evidence of impact climate-smart agriculture in Africa (No. 86). Copenghagen.

Olorunfemi, T. O., Olorunfemi, O. D., \& Oladele, O. I. (2019). Determinants of the involvement of extension agents in disseminating climate smart agricultural initiatives: Implication for scaling up. Journal of the Saudi Society of Agricultural Sciences, (xxxx). https://doi.org/10.1016/j. jssas.2019.03.003

Ovalle-rivera, O., Läderach, P., Bunn, C., \& Obersteiner, M. (2015). Projected shifts in coffea arabica suitability among major global producing regions due to climate change. PLOS ONE, 10(4), 1-13. https://doi. org/10.1371/journal.pone.0124155

Perdoná, M. J., \& Soratto, R. P. (2015). Higher yield and economic benefits are achieved in the macadamia crop by irrigation and intercropping with coffee. Scientia Horticulturae, 185, 59-67.

Pham, Y., Reardon-Smith, K., \& Cockfield, G. (2019). The impact of climate change and variability on the Coffee Production: A systematic review. Climatic Change, 24(2), 173-188. https://doi.org/10.1127/ metz/2015/0530

Prastowo, B., Karmawati, E., Rubijo, Siswanto, Indrawanto, C., \& Munarso, S. J. (2010). Budidaya dan Pasca Panen Kopi. Bogor: Pusat Penelitian Perkebunan.

Rahn, E., Vaast, P., Läderach, P., Asten, P. Van, \& Jassogne, L. (2018). Exploring adaptation strategies of co ff ee production to climate change using a process-based model. Ecological Modelling, 371(July 2017), 76-89. https://doi.org/10.1016/j. ecolmodel.2018.01.009

Ranjitkar, S., Sujakhu, N. M., Merz, J., Kindt, R., Xu, J., Matin, M. A., ... Zomer, R. J. (2016). Suitability analysis and projected climate change impact on banana and coffee production zones in Nepal. Plos One, 11(9), 1-18. https://doi.org/10.1371/journal. pone. 0163916

Ray, D. K., Gerber, J. S., Macdonald, G. K., \& West, P. C. (2015). Climate variation explains a third of global crop yield variability. Nature Communications, 6, 1-9. https://doi.org/10.1038/ncomms6989

Robertson, G. P., Paul, E. A., \& Harwood, R. R. (2000). Greenhouse gases in intensive agriculture: Contributions of individual gases to the radiative forcing of the atmosphere. Science, 289(5486), 1922-1925. https://doi.org/10.1126/ science.289.5486.1922

Rosiana, N. (2019). Indonesian coffee competitiveness and exports through dynamic system approach. IPB.

Santos, J. C. F., Cunha, A. J. D. A., Ferreira, F. A., Santos, R. H. S., Sakiyama, N. S., \& Lima, P. C. D. E. (2016). Herbaceous legumes intercropping in weed management of the bearing coffee crop. ASIC 24th International Conference on Coffee Science, 5(1), 770774. https://doi.org/10.15640/jaes.v5n1a10 
Sarirahayu, K., \& Aprianingsih, A. (2018). Strategy to improving smallholder coffee farmers productivity literature study. The Asian Journal of Technology Management, 11(1), 1-9.

Sartika, S. R., \& Karyani, T. (2018). A case study: Accessibility of coffee farmers towards credit to bank as financial institution. Jurnal AIP, 6(2), 87-98.

Scalco, M. S., Guimarães, R. J., Colombo, A., Dominghetti, A. W., \& de Matos, N. M. S. (2014). Drip irrigation in coffee crop under different planting densities: Growth and yield in southeastern Brazil. Revista Brasileira de Engenharia Agricola $e$ Ambiental, 18(11), 1116-1123. https:// doi.org/10.1590/1807-1929/agriambi. v18n11p1116-1123

Schroth, G., Laderach, P., Cuero, Sofia, D. B., Neilson, J., \& Bunn, C. (2015). Winner or loser of climate change? A modeling study of current and future climatic suitability of Arabica coffee in Indonesia. Reg Environ Change, 15, 1473-1482. https://doi. org/10.1007/s10113-014-0713-x

Sinkevičienè, A., Jodaugienè, D., Pupalienè, R., $\&$ Urbonienè, M. (2009). The influence of organic mulches on soil properties and crop yield. Agronomy Research, 7(I), 485-491.

Sujatmiko, T., \& Ihsaniyati, H. (2018). Implication of climate change on coffee farmers' welfare in Indonesia. IOP Conference Series: Earth and Environmental Science, 200(1). https://doi. org/10.1088/1755-1315/200/1/012054

Supriadi, H. (2015). Budidaya tanaman kopi untuk adaptasi dan mitigasi perubahan iklim. Perspektif, 13, 35-48. https://doi. org/10.21082/p.v13n1.2014.

Supriadi, H., \& Pranowo, D. (2016). Prospek pengembangan agroforestri berbasis kopi di Indonesia. Perspektif, 14(2), 135. https:// doi.org/10.21082/p.v14n2.2015.135-150

Syakir, M., \& Surmaini, E. (2017). Perubahan iklim dalam konteks sistem produksi dan pengembangan kopi di Indonesia. Jurnal Litbang Pertanian, 36(2), 77-90. https:// doi.org/10.21082/jp3.v36n2.2017.p77-90

Tesfaye Shimber, G., Razi Ismail, M., Kausar, H., Marziah, M., \& Ramlan, M. F. (2013). Plant water relations, crop yield and quality in coffee (Coffea arabica L.) as influenced by partial root zone drying and deficit irrigation. Australian Journal of Crop Science, 7(9), 1361-1368.

Thornton, P. K., Whitbread, A., Baedeker, T., Cairns, J., Claessens, L., Baethgen, W., ... Keating, B. (2018). A framework for priority-setting in climate smart agriculture research. Agricultural Systems, 167(August), 161-175. https://doi. org/10.1016/j.agsy.2018.09.009

Torquebiau, E., Rosenzweig, C., Chatrchyan, A. M., Andrieu, N., \& Khosla, R. (2018). Identifying climate-smart agriculture research needs. Cahiers Agricultures, 27(2). https://doi.org/10.1051/cagri/2018010

Tucker, C., Eakin, H., \& Castellanos, edwin J. (2010). Market shocks and climate variability: The coffee crisis in Mexico. Global Environmental Change, 20(November), 23-32. https://doi. org/10.2307/3674435

van der Vossen, H., Bertrand, B., \& Charrier, A. (2015). Next generation variety development for sustainable production of arabica coffee (Coffea arabica L.): A review. Euphytica, 204(2), 243-256. https:// doi.org/10.1007/s10681-015-1398-Z

Verburg, R., Rahn, E., Verweij, P., van Kuijk, M., \& Ghazoul, J. (2019). An innovation perspective to climate change adaptation in coffee systems. Environmental Science and Policy, 97(September), 16-24. https://doi. org/10.1016/j.envsci.2019.03.017

Wahyudi, T., \& Jati, M. (2012). Challenges of sustainable coffee certification in Indonesia. ICO Seminar on the Economic ICO Seminar, (September), 1-14. 
Workie, T. G., \& Debella, H. J. (2018). Climate change and its effects on vegetation phenology across ecoregions of Ethiopia. Global Ecology and Conservation, 13, 1-13. https://doi.org/10.1016/j.gecco.2017. e00366

Youkhana, A., \& Idol, T. (2009). Tree pruning mulch increases soil $\mathrm{C}$ and $\mathrm{N}$ in a shaded coffee agroecosystem in Hawaii. Soil Biology and Biochemistry, 41(12), 25272534. https://doi.org/10.1016/j.soilbio.20 09.09.011

Yuliasmara, F. (2016). Strategi mitigasi perkebunan kopi menghadapi perubahan iklim. Warta Pusat Penelitian Kopi Dan Kakao Indonesia, 28(3), 1-7.

Yuliasmara, Fitria. (2017). El nino effect on coffee growth and productivity on several agroforestry systems in Gumitir mountain coffee farms, East Java, Indonesia. Pelita Perkebunan, 33(3), 168-179.

Zullo, J., Hilton, J., Pinto, S., Delgado, E., Maria, A., \& Ávila, H. De. (2011). Potential for growing Arabica coffee in the extreme south of Brazil in a warmer world. Climatic Change, 109, 535-548. https://doi. org/10.1007/s10584-011-0058-0 